\title{
PRESENT TENDENCIES IN LANDSCAPE PLANNING AND RECOGNITION OF THE OPINION OF LOCAL CITIZENS ON THE EXAMPLE OF THE TISZAZUG
}

\section{PÉTER CSORBA}

Department of Landscape Protection and Environmental Geography University of Debrecen, Debrecen

Email: csorba.peter@science.unideb.hu

Received 10 March 2021, accepted in revised form 11 April 2021

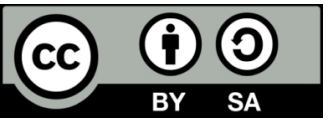

\begin{abstract}
A survey based on online and face-to face interviews with 104 persons who live in the Tiszazug in the central part of the Great Hungarian Plain. According to the answers the character of the landscape here would change dramatically by disappearance of oxbow lakes, floodplain forests and vineries. The decreasing population and aging of the citizens result in decreasing intensity of landuse, increasing number of abandoned buildings and the attractiveness of the landscape is spoiled by illegal waste disposals and weedy water banks.
\end{abstract}

Keywords: landscape character, landscape identity

\section{Introduction}

Alteration of European geographic landscapes are characterized by the following tendencies almost all over the continent according to Van Mansvelt, J.D. and Pedroli, B. (2003):

- natural diversity (landscape diversity) decreases, at the same time landscape functional and visual uniformity increases usually,

- there is a strong polarization in landuse, that is abandoned, or protected fragments appear in the vicinity of intensely used parts of the landscape,

- There are series of newly formed landscape fragments which do not fit into regional or global ecological structures and
- landscape development is not a consequent continuation of the previous centuries, but there is a radical tearing from historical roots in many places. New landscapes are not "growing into" the previous landscape structure, but „have been superimposed rather than being integrated" (Antrop, M. 2005).

One reason for the before mentioned undoubtedly widespread process is that social approach to rural landscapes mainly has changed substantially. In landscapes previously ruled by agriculture most people seek for clean air, water potential, nature protection, recreation and aesthetic function; and a countryside free from lights and noise (Brandt, J. - Vejre, H. 2004). Social value of many European landscapes originated today not from their agricultural productivity or 
raw material potential but their suitability for recreational or nature protection purposes. This is the base for the European Union compensation mechanism what provide financial support for environmental friendly ways of use of agricultural lands in order to conserve the quality of the environment, surface and ground waters, a vegetation free of weeds, unpolluted, uneroded soils by lower intensity disturbances and use of pesticides what has a growing importance for the society.

\section{European landscape protection measures and involvement of local communities}

According to Antrop, the first warning what have triggered a strong response about problems with the health of European landscapes had been published in the Dobriš report (Stanners, D. - Bourdeau, P. 1995). Since then the following topics have an emphasized importance at every landscape ecological, landscape geographical and landscape architectural conferences:

- landscape diversity,

- multifunctional landscape use and

- the issues of landscape character.

Finally, scientific warnings have reached the limen of decision makers what resulted in the European Landscape Convention in 2000 and it put in force in 2004 when the number of countries which joined the convention reached the required limit. The joining process came to its end with acceptance of the law CIV of 2007 in Hungary. (Csorba P. et al. 2017a).

We do not share Antrop's pessimistic opinion from every aspect. An elementary demand appeared for protection of national landscapes in Asia, South- and Central America and especially in Europe in the last decade. From another aspect we could say that landscape protection, individual-, groupand national identity linked to landscapes has become a new battlefield in the struggle against globalization (Csorba P. 2010).
There were opinion polls on attitude to different landscapes in many European countries in the last few decades. The "what kind of landscapes would we like" type surveys can fulfill the requirements of statistical reliability today. As a result the description of the "real English", the "genuine German", the "typical French", the "pure Italian",; and the characteristic Alpine, Tuscan, Sicilian or Dalmatian landscapes are getting outlined (Wascher, D. - Jongman, R. 2000, Pedroli, B. et al. 2007, Csorba P. Csatári B. 2017b)

Due to the mosaic like natural geographical endowments, Europe is originally has been characterized by very high landscape diversity except for its eastern plain parts. For this reason, the habitants of the continent banter to many different landscape types. It is hard to reach a social consensus on what is the "true" national landscape type in European countries with large area. This task seems to be easier in smaller countries where there is a smaller selection of landscapes, or countries where landscape diversity is lower. There were much less debate on typical Polish, Russian or Swedish landscapes for instance, than in the case of typical Italian, French or Spanish landscapes.

Beside visual attractivity a common feature of the accepted national landscapes is that they are closely related to important places of the history of the nation, or to scenes of the life of an influential historical person. Real national landscapes are permanently ruled historical core areas of a country -that is Dalarna for the Swedish, the Rhineland region for the German, Tuscany for the Italian. (It is a good counterexample that it is a national tragedy for the Armenians that the Mount Ararat belongs to Turkey today.) In the case of many nations the predestinated role of some ancient sacred places has remained yet. The Krivan and Sitno are national mountains for the Slovakians, while according to Czech myths there are warriors hiding on Blaník who come to help in cases when there is a national emergency... The Brocken what is the highest peak of the Hartz mountains is 
believed to be a meeting place for witches in German mythology.

There are some common characteristic of national landscapes considered as typical:

Intense, mid altitude mountainous relief merely.

- Open water bodies, rivers, lakes seas.

- Mosaic like vegetation cover with a few visibly artificial objects like planted forests only.

- Dominance of traditional (small plot) agricultural landuse is frequent.

- Built up areas occupy not more than 15$20 \%$ of the horizon.

- Historic buildings like fortresses, castles, gardens, harbors, roadside tree rows.

\section{Determination of the character of landscapes}

However, among the landscape elements considered as favorable there are natural, semi natural and artificial elements. Their ratios to each other, their spatial pattern and complexion altogether can result in an exceptionally advantageous landscape appearance.

Among natural landscape forming factors

- character of relief,

- close-to-nature vegetation,

- water bodies,

- connecting surfaces between landscape patches, the so-called edge effect,

- patch pattern paly a decisive role.

In the case of semi natural elements that is agroecosystems and planted forests the size, shape, arrangement and contours of the plots, direction of plots on sloping surfaces are the factors what result in individual landscape character. Color of the vegetation can become an important "landscape dressing" factor for example in the case of the sharp landscape forming yellow squares of canola fields in the spring or the violet plots of lavender plantations. Vineyards and orchards have a very strong landscape forming effect along with olive groves, the characteristic umbrella pines and European cypress trees in the Mediterranean. However, there are significant regional differences in the shape of haystacks for instance (Swanwick C. 2002).

In the case of anthropogenic landscape forming objects exposition of the area occupied by the settlement is important - for instance whether the settlement is situated on hills on smaller mountains or riverbanks. A steeple instead of a mobile tower should emerge from a settlement nestled in a beautiful landscape. The settlement should fit into the neighboring landscape with decreasing height of the buildings towards its borders. High raised blocks of flats should not suppress the silhouette of the historical settlement center. Some special buildings visible from a great distance like medieval fortress walls, bastions, chapels on calvaries, sweeps, wine press houses can strengthen the individual attractiveness of some landscapes. Landscape forming forces can be the shape of the houses like high alpine roofs, reed roofs, or "typical Hungarian farm houses with white walls and red roofs" The dazzling white cubes of Mediterranean houses, with the shady narrow network of streets; or the appearance of English settlements proportioned by parks and green grass spots and waving waters of harbors divided by piers are visible from far, from a panoramic view of the landscape.

\section{Survey on the opinion of the citizens of the Tiszazug on their landscape environment}

A survey based on online and face-to face interviews with 104 persons who live in the Tiszazug or has local attachments was carried out in the frame of an EU KEHOP project. The questionnaire was sent out by the Geographical Museum of the Tiszazug. $90 \%$ of the questions were answered. There were some questions what was not answered by $10-17$ persons. 


\section{Personal composition of the responder population}

$65 \%$ of the responders is female, $35 \%$ is male. There were not significant differences in the age distribution of the female/male responders. There was a higher ratio of female responders in the human profession group; while the ratio of male responders was higher in the technical profession group. The online survey was filled in mainly by responders from the younger age groups. However, this disproportion was at least partly balanced by the higher number of older age group responders in the face to face interviews.

\section{Nature of local attachment}

Distribution of the responders by settlements was the following: $67 \%$ Tiszaföldvár $\quad 12 \%$ - Cibakháza, $\quad 8-8 \%$ Tiszakürt, and Nagyréve. Further $5 \%$ is divided among Cserkeszőlő, Tiszasas, Szelevény, Tiszainoka, Tiszaug and Csépa. The population of the sample area is $24,000.46 \%$ of the responders live at Tiszaföldvár, what means that settlement is overrepresented in the sample (46-67\%). However, the sample cover all independent settlements that is there was at least one responder from all settlements.

On the base of the data vast majority of the responders have well established knowledge and experience on the landscape

Table 1. Main elements of the free description of the landscape

Assignment in an order according to the frequency of mentioning: color tones:

darkest: mentioned very frequently (90-100\%)

green: mentioned frequently $(60-90 \%)$,

light green: mentioned several times (30-60\%),

lightest: rare, 1-2 mentioning (10-30\%)

\begin{tabular}{|c|c|c|c|c|c|c|c|}
\hline RELIEF & WATERS & VEGETATION & ANIMALS & AGRICULTURE & SETTLEMENT & POPULATIONG & $\begin{array}{c}\text { TONAL } \\
\text { ELEMENT }\end{array}$ \\
\hline \multirow[t]{2}{*}{$\begin{array}{l}\text { plain, } \\
\text { lowland }\end{array}$} & $\begin{array}{l}\text { Tisza, living } \\
\text { waters }\end{array}$ & $\begin{array}{l}\text { floodplain } \\
\text { forests }\end{array}$ & $\begin{array}{l}\text { fish, } \\
\text { fishing }\end{array}$ & $\begin{array}{l}\text { good agricultural } \\
\text { lands }\end{array}$ & $\begin{array}{l}\text { small villages } \\
\text { and towns, }\end{array}$ & aging & silence \\
\hline & & & & cultivated lands & roads levees & & tranquility \\
\hline $\begin{array}{l}\text { slightly } \\
\text { aslope, hilly } \\
\text { in some } \\
\text { places }\end{array}$ & $\begin{array}{l}\text { oxbow } \\
\text { lakes }\end{array}$ & arboretum & birds & $\begin{array}{l}\text { orchards, large } \\
\text { gardens }\end{array}$ & spas & $\begin{array}{c}\text { ancient } \\
\text { farmers' } \\
\text { culture }\end{array}$ & $\begin{array}{l}\text { sounds of } \\
\text { nature }\end{array}$ \\
\hline \multirow[t]{2}{*}{$\begin{array}{l}\text { high } \\
\text { riverbanks }\end{array}$} & $\begin{array}{l}\text { medicinal } \\
\text { waters }\end{array}$ & $\begin{array}{l}\text { grasslands on } \\
\text { alkaline soils }\end{array}$ & & vineries on sand & $\begin{array}{l}\text { delapidated } \\
\text { properties }\end{array}$ & reminiscences & few people \\
\hline & & & & fallows & & & \\
\hline river terraces & $\begin{array}{l}\text { floodplain } \\
\text { swamps }\end{array}$ & tree rows & hunting & $\begin{array}{l}\text { ancient spear } \\
\text { orchards on } \\
\text { floodplains }\end{array}$ & steeples & $\begin{array}{l}\text { friendly } \\
\text { people }\end{array}$ & $\begin{array}{c}\text { "dark } \\
\text { Tiszazug" }\end{array}$ \\
\hline \multirow[t]{2}{*}{ kurgans } & $\begin{array}{l}\text { alkaline } \\
\text { swamps }\end{array}$ & & & $\begin{array}{l}\text { diversified } \\
\text { agriculture }\end{array}$ & & & $\begin{array}{l}\text { good air } \\
\text { quality }\end{array}$ \\
\hline & & & & $\begin{array}{l}\text { farmers' } \\
\text { agricultural } \\
\text { history }\end{array}$ & & & \\
\hline \multirow[t]{3}{*}{ sand ridges } & $\begin{array}{l}\text { sandy } \\
\text { riverbanks }\end{array}$ & planted forests & $\begin{array}{l}\text { frog and } \\
\text { mosquito } \\
\text { music }\end{array}$ & alkaline soils & monuments & lack of jobs & \\
\hline & & flowers & & $\begin{array}{l}\text { large plough } \\
\text { lands }\end{array}$ & & & \\
\hline & & pastures & & & & & \\
\hline
\end{tabular}


Table 2. Importance of individual landscape elements (dominant categories in yellow)

\begin{tabular}{lccc}
\hline & $\begin{array}{c}\text { very } \\
\text { important }\end{array}$ & important & less important \\
\hline Tisza & $92 \%$ & $5 \%$ & $3 \%$ \\
lakes, oxbow lakes & $71 \%$ & $19 \%$ & $10 \%$ \\
flood prevention levees & $50 \%$ & $35 \%$ & $15 \%$ \\
rich floodplain vegetation & $45 \%$ & $40 \%$ & $15 \%$ \\
forest patches & $40 \%$ & $45 \%$ & $15 \%$ \\
extensive plough lands & $50 \%$ & $42 \%$ & $8 \%$ \\
extensive pasture grasslands & $35 \%$ & $50 \%$ & $15 \%$ \\
stockbreeder yards & $15 \%$ & $40 \%$ & $45 \%$ \\
vineries, orchards & $55 \%$ & $40 \%$ & $5 \%$ \\
little villages & $40 \%$ & $50 \%$ & $10 \%$ \\
motorways & $5 \%$ & $15 \%$ & $80 \%$ \\
silence & $80 \%$ & $15 \%$ & $5 \%$ \\
spas & $50 \%$ & $35 \%$ & $15 \%$ \\
traditional buildings & $60 \%$ & $30 \%$ & $10 \%$ \\
\hline
\end{tabular}

and its changes. $78 \%$ of the responders like their settlement and only 5\% answered that they do not like the settlement where they live. However, there was a relatively high ratio of the responders (17\%) who have not answered this question.

The distribution of the answers between responders under/ over 45 year has been examined. Both age group has considered

Table 3. Favorite locations

\begin{tabular}{ll}
\hline $\begin{array}{l}\text { parks and gardens within } \\
\text { settlements }\end{array}$ & $25 \%$ \\
along water flows & $65 \%$ \\
lake banks, fisheries & $30 \%$ \\
vineries, orchards & $25 \%$ \\
forest hiker sites & $40 \%$ \\
grasslands & $25 \%$ \\
swamps, wetlands, & $15 \%$ \\
other & $10 \%$ \\
\hline
\end{tabular}

river Tisza, the oxbow lakes and silence as characteristic features of the landscape. There are 4 factors from the 14 ones enlisted in the survey where statistical differences have been found between the age groups, since older responders have considered spas, traditional buildings, forest patches and stockbreeding as more important landscape elements than younger responders.

Table 4. Why do you like it?

\begin{tabular}{lc}
\hline easy to access & $30 \%$ \\
water bank & $55 \%$ \\
panorama & $5 \%$ \\
naturalness & $75 \%$ \\
tranquility & $90 \%$ \\
$\begin{array}{l}\text { landscape beauty } \\
\text { especial mood }\end{array}$ & $80 \%$ \\
$\begin{array}{l}\text { personal experience, memory } \\
\text { cultural value, nice-looking } \\
\text { buildings } \\
\text { the landscape as a whole is } \\
\text { attractive }\end{array}$ & $35 \%$ \\
\hline
\end{tabular}




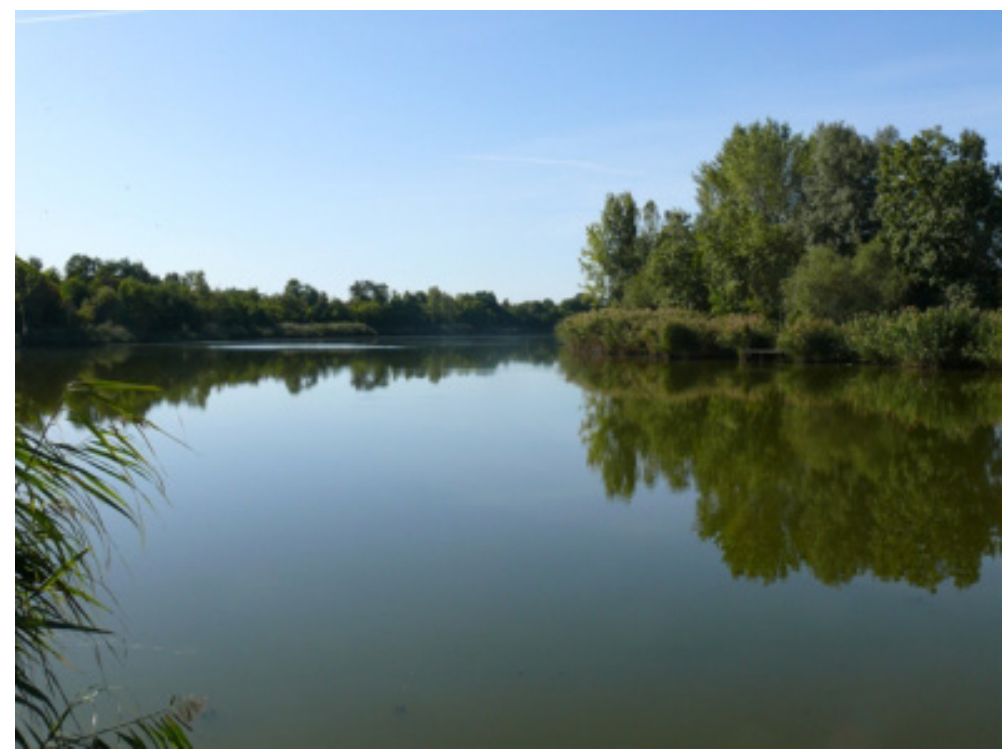

1. photo. The most beloved landscape type: the oxbow lakes

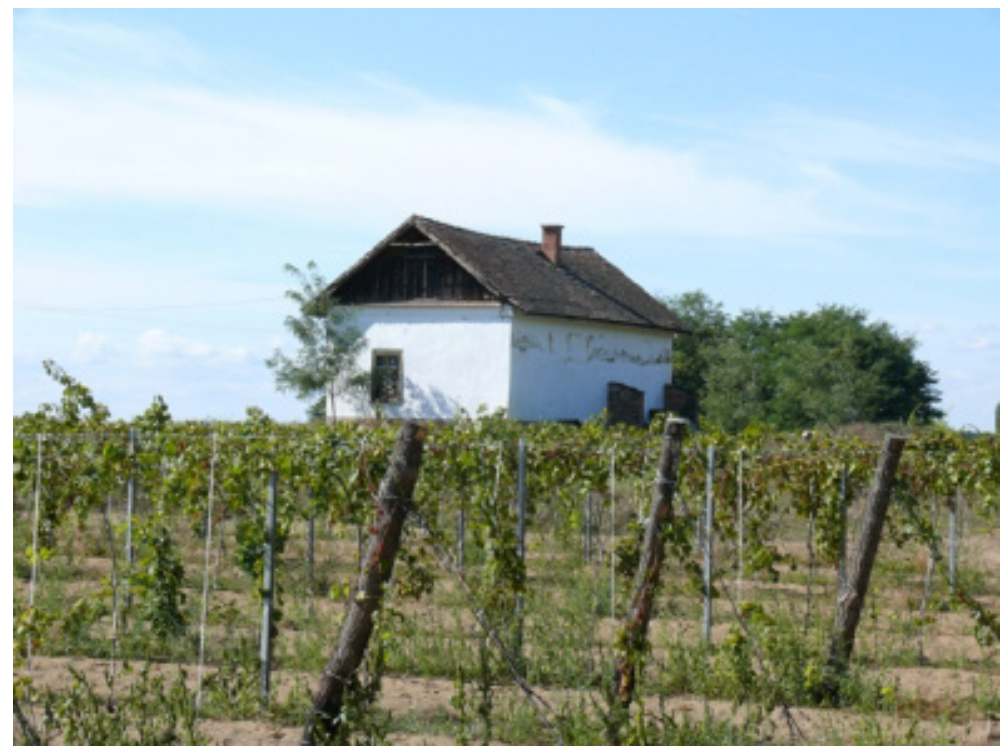

2. photo. Traditional vinerie 
Table 5. Disappearance of which landscape elements would you consider as dangerous for the present character of the landscape?

desiccation of oxbow lakes
disappearance of forest patches and floodplain forests
disappearance of close to nature areas, cultivation, build up
siltation of oxbow lakes
disappearance of vineries
decrease of cultivated lands
disappearance forestation, weeding of pastures
depopulation of villages
disappearance birds
abandonment of ploughlands
disappearance forest belts
disappearance of ancient buildings
disappearance of mosaicness
buildup

Table 6. What kind of landuse problems have you faced yet? ratio of yes answers (\%)

\begin{tabular}{ll} 
abandoned vineries and orchards & $88 \%$ \\
abandoned buildings & $84 \%$ \\
neglected, rubbishy margin of villages & $83 \%$ \\
bad, crowded roads & $81 \%$ \\
reedy, swampy eutrophicating water bodies & $67 \%$ \\
unsettled stockbreeding yards & $65 \%$ \\
untidy forests, skimpy tree rows & $60 \%$ \\
electric cables disturbing the sight & $59 \%$ \\
dust pollution, traffic noise & $58 \%$ \\
neglected, polluted lakes, oxbows & $55 \%$ \\
weedy pastures & $54 \%$ \\
abandoned, run-down water bank buildings & $51 \%$ \\
plough lands out of crops & $50 \%$ \\
too large uniform ploughland areas & $49 \%$ \\
crowded, extraneous buildup & $46 \%$ \\
\hline
\end{tabular}


Answers of the younger age group (under 45 years) have been shorter and more simplistic (sometimes irreal: "if river Tisza would disappear" for instance), while more factors have appeared in the answers of the older age group.

Judgement on 11 from the 15 problems listed above has been the same in the younger and the older age group of responders. However, occurrence of neglected, polluted lakes, oxbows, untidy forests and dust pollution have been mentioned on a higher frequency in the older age group, while electric cables disturbing the sight have been mentioned more frequently by the younger age group.

\section{Summary}

There have been major changes in landuse in Europe apart from its most eastern parts during the last decades. The ratio of traditional agricultural areas and mining fields has decreased remarkably, while there has been a significant growth in the extent of builtup, nature protection and recreation areas. Local citizens usually have an indisposition for large scale alterations of the accustomed landscape environment, what leads to less familiar feelings. Landscape protection what means conservation, reshaping or rehabilitation of the visual approach of the landscape have an increasing social support recently.

So called participative planning that is

Table 7: What kind of landscape changes have you experienced yet? coloring according to the frequency of mentioning -darkest green: mentioned very frequently (mentioned in 90-100 \% of the questionnaires) -green: mentioned frequently (mentioned in $60-90 \%$ of the questionnaires), -light green: mentioned several times (mentioned in 30-60 \% of the questionnaires), -lightest green: mentioned rarely (mentioned in 10-30 \% of the questionnaires only)

growth of vehicular traffic
bad quality of roads
garbage
disappearance of vineries
growing area of plough lands out of crops
neglected, abandoned buildings
untidy water banks
weeding
lack of stock breeding
ugly light structure building
drainage of sewage into oxbow lakes
untidy channels
migration from the region
neglected levees
desiccation of wetland habitats
lack of jobs
grass has not been cut
stray dogs


involvement of local citizens in the planning process is a general EU objective today. There is a spectacular growth in the number of public hearings and questionnaires with this aim. Results of a "what do local citizens think about their own landscape environment" type survey have been presented in the second part of the present paper.

According to the answers of 104 responders from the Tiszazug microregion the character of the landscape in that microregion would change most dramatically by disappearance of oxbow lakes, floodplain forests and vineries. They recognize that the decreasing population and aging of the citizens result in decreasing intensity of landuse, growing extent of areas what are out of crops and an increasing number of abandoned buildings on the level of the landscape. Severe problem is the bad quality of public roads. The attractiveness of the landscape is spoiled by frequent illegal waste disposals and weedy water banks.

\section{References}

Antrop, M. 2005: Why landscapes of the past are important for the future. Landscape and Urban Planning, 70.1/2. pp. 21-34.
Brandt, J. - Vejre, H. 2004: Multifunctional landscapes. WIT Southampton, UK.140 p.

Csorba P. 2010: A földrajzi tájakhoz füződő identitástudat rétegei. Tájökológiai Lapok, 8. 1. pp. 3-21.

Csorba P. - Pádárné Török É. - Kincses K.: 2017a: Megjelent a Nemzeti Tájstratégia (2017-2026) kormányhatározat. Földr. Közlemények 141. 4. pp. 399-406.

Csorba P. - Csatári B. 2017b: Tájföldrajz és táji önazonosság. Magyar Tudomány, 2017. március, pp. 284-292.

Swanwick, C. and Land Use Consultants 2002: Landscape character assessment guidance for England and

Scotland. Countryside Agency and Scottish Natural Heritage. 84 p.

Stanners, D. - Bourdeau, Ph. (Eds.) 1995: Europe's environment - European Env.Agency, Coppenhagen, $676 \mathrm{p}$.

Van Mansvelt J.D. - Pedroli, B. 2003: Landscape: a matter of identity and integrity. In: Palang, $\mathrm{H}$. - Fry, G.

(eds.) Landscape interfaces: cultural heritage in changing landscapes. Kluwer,Dordrecht pp. 375-394.

Wascher, D. - Jongman, R. (Eds.) 2000: European landscapes, Classification, assessment and conservation.

European Environmental Agency, Coppenhagen, 99 p. 